\title{
Understanding collaborative governance in decentralizing Indonesia:
}

\author{
A dimensional approach to emerging intergovernmental \\ and cross-sectoral collaboration
}

Mahesti OKITASARI*, Tetsuo KIDOKORO*

\begin{abstract}
Collaborative governance is a topical regional issue and is considered as a tool to establish, steer, facilitate, operate and monitor arrangements to address cross-jurisdiction public policy problems. It has been receiving attention in the developed countries for decades before starting to emerge in many developing countries in the 1990s. Following the decentralization in 1999, Indonesia experienced the sudden transformation from a centralized to a decentralized system. The rapid change of system together with increasing demand of urban service push the local governments to search for a new mechanism of regional governance through collaboration that correspond to the current system. This paper aims to identify the structure of current collaborative governance in Indonesia through in depth analysis of the existing institutional structure of horizontally and vertically linked organizations in four metropolitan regions. Findings suggest that the structure and variation of collaborative governance varied according to the tendency of vertical and horizontal interaction adopted in the jurisdiction. Interaction between actors, thus, plays consequential role in the development of collaboration that are more visible in institutionally fragmented regional setting.
\end{abstract}

Keywords: governance, collaboration, regional planning, decentralization, Indonesia.

\section{Introduction}

In recent years, as urbanization spilled over the city administration boundary, urban problems are getting more scaled up to the regional level where the city alone as a single player is no longer enough to overcome the challenges. To make regions more resilient and sustainable with limited resource possessed, cities need to collaborate with their neighbors and other local actors, deliberately making collaboration to become an important strategy in the field of urban and regional planning. Historically, urban problems were solved and the resolution was planned at the individual local government level. However, recently more and more of those problems require resolution at the regional level. This transition is elaborated by Brenner (2002), implying the movement from city to regions the new politics of scale.

In light of a fragmented urban political landscape and the segregation of power among governments, arranging collaborative activities between cities are becoming undeniably

* Department of Urban Engineering, The University of Tokyo

E-Mail: okita@urban.t.u-tokyo.ac.jp 
challenging in Indonesia. The new governance system induced by the regional autonomy and fiscal decentralization policy in 1999, originally intended to make government closer to the bottom line by empowering local and provincial governments (Firman, 2010a). However, many did not expect the growing local egocentrism fueled by local autonomous power. As higher levels of government's authority to local government is reduced, the system sees a declining influence of regional governance by the provincial government (Situmeang, 2011). To curb this negative development, the central government issued a new regulation in 2008 to promote collaboration and to push regional governance into a more prominent place. The new regulation also opened many possibilities for the local government to form intergovernmental and cross-sectoral collaboration, especially in the metropolitan region after the establishment of a supra-level government, such as metropolitan authority, is deemed unfit to the current governmental system (Firman, 2010b).

With the pushing of the quest for broadening the new regionalism in the Indonesian planning system, the emerging of collaborative governance is receiving increased attention from scholars, government officials and civic leaders. This study acknowledges that not every collaborative arrangement develops into a successful one and none of collaborative governance across policy fields is managed similarly, e.g. collaboration for social issue may be different with collaboration for local economic development. Building on this debate, this study argues that although managed differently, the institutional structure of collaborative governance shares similarity across sectoral issues in one region since institutions are inherently location-based and politically bonded, particularly for the unitary type of government such as Indonesia. Hence, this study intends first to deepen understanding of the decentralized institutional structure in shaping the new regionalism from the viewpoint of local government. By demonstrating the various ways in which interaction among actors are pursued, the process of designing and administering collaborative governance at the local level can be projected.

Why local government? Local government is the subject to varying influences from and interdependence with other levels of government, making multilevel governance a relevant feature of urban policy (Seller, 2002). Cities are also useful units of analysis for examining the various characteristics of collaborative governance due to the potentially strategic nature of the activity. Accordingly, to understand the different approaches to regionalism and collaborative governance, it is necessary to have a perspective on the local governance systems, how they developed, the influences, and the differences in their approaches to service delivery.

To draw an elaborate perspective, four metropolitan regions along the most populated development corridor in Indonesia; Jakarta, Yogyakarta, Surabaya, and Denpasar are selected to conduct comparative analysis of their collaborative mechanism. While Jakarta and Surabaya are representatives of metropolitan collaboration established prior to the decentralization, Yogyakarta and Denpasar are examples of emerging collaborative arrangements initiated by local governments after they gained local autonomous power following the decentralization.

This paper is divided into six parts. The first part reviews the relevant literatures on collaboration, including intergovernmental and cross-sectoral as well as highlighting some theoretical issues. The second part introduces the background of the study area and the overview of collaborative processes. The third part explains the methodology used in this research, procedure of data collection and limitation. The fourth part consists of in depth investigation of collaborative governance using dimensional analysis. The fifth part elaborates the findings of the empirical studies. In the concluding part, policy implications are discussed. 


\section{Collaborative Governance}

Governance is a topic that has been studied by organizational scholars, both in the business organizations and the nonprofit context (Mizruchi, 1983; Fama and Jensen, 1983; Provan, 1980). Concern about collaborative governance among cities' stakeholders have produced some of the most important and enduring questions across the field of political science, regional planning and public administration. The distinction between government and governance is emphasized in much of the contemporary work of local politics and public administration and has coincided with the rise of the new regionalism movement (Rhodes, 1997; Wheeler, 2002; Feiock, 2004). To many, governance entails a collective decision-making process in which governmental organizations at all levels, nonprofit organizations, and the private sector work together in new partnerships for the collective social benefit (Stoker, 2000), which span across jurisdiction (Feiock, 2004) or operate within hierarchies (Agranoff and McGuire, 2003). The intergovernmental collaborative arrangement together with interdependencies with the nongovernmental sector and the complexity of the relations among actors bring about every new challenges and potential development in regional and metropolitan governance.

The organization of governance and public authority in regional level is a long standing and contentious issue in urban studies. Advocates of neo regionalism argue that the fragmentation of policy making among multiple governmental units diminishes problems of concentrated power and can promote competition and innovations between units, but it also imposes inefficiencies as decisions by one governmental unit and inflicts positive and negative externalities on others (Feiock, 2004). Arguments that the consolidation of governments through coordinated regional planning and streamlined development approval does not enhance economic development as expected have also been employed by several studies (Carr and Feiock, 1999; 2003).

The need to address pressing regional problems without having renounced autonomy or created concentrated power calls for collaborative governance. This type of decentralized approach to regionalism emphasizes self-governance through horizontally and vertically linked organizations. On this issue, collective action theory provides the building blocks to understand a system of metropolitan governance without a metropolitan government (Feiock, 2004). This theory posits that local governments can act collectively to create a civil society that integrates a region across multiple jurisdiction through a web of voluntary agreements and associations and collective choices. Thus, understanding the collaborative arrangement characteristics and formation is undeniably an important step to have a clear idea of collaborative governance.

Investigations of successful cooperation among decentralized actors challenged with resource sharing issues provide a useful starting point for understanding how collaboration can be forged among local actors (Weber, 1998; Lubell et all, 2002). The recent study by Luo and Shen (2009) provided many insights on the building of research in city to city collaboration -in their study, city to city collaboration covers both intergovernmental and cross-sectoral collaboration- especially regarding the formation process of cooperation and actor partnership. Through case studies in the Yangtze river delta region in China, the study mapped how collaborations were mobilized and how stakeholders interacted. It argues that the effectiveness of collaboration depends on collaborative mechanism, the nature and the scope, partner selection and the roles of actors. However, as much as understanding the historical formation and process of collaboration is important, the challenge for researchers is to find a way dissecting the extent and nature of the process affected by behaviors of all actors involved. Hence, acknowledging that there are various types of collaborations by just looking at the array 
of actors involved, breaking the collaborative process down into its parts and sequences is needed to make suggestions regarding how to manage the process forward.

In terms of Indonesian context, metropolitan regions in Indonesia vary from the number of local governments involved, the size of population, area covered and its degree of primacy. Regions are also diversified significantly in term of the political situation and culture due to the Indonesian pluralistic nature built upon various ethnic groups. To put into words, with these fragmented attributes to put one single type of collaborative governance as the basis for lasting regional partnership, resurgence and effectiveness of planning as well as the relationship between distinctive and often opposing urban system, is impossible in nature. Therefore, some issues remain to be addressed. Is it possible to systematically measure different approaches inherent in the Indonesian collaborative governance? How various intergovernmental and cross-sectoral relations are mobilized? On which mechanism each relations respond to? What kind of collaborative governance forms the local actors creates based on relations and networks in their regions?

\section{Background of Case Studies}

\subsection{Yogyakarta (Kartamantul Metropolitan Region)}

There are three local governments in Yogyakarta (Kartamantul Metropolitan Region; from this point forward referred as Yogyakarta); one municipality (Yogyakarta) and two regencies (Sleman and Bantul). Located in the special province of Yogyakarta the metropolitan area covers as about $1,114 \mathrm{~km}^{2}$ with the total population is 2.4 million as of 2010 .

The joint cooperation was initiated by local governments in 2001, not long after the decentralization law was enacted, with the support from the provincial government, making it essentially as a bottom-up type of cooperation. Prior to the establishment of the joint cooperation, the management of infrastructure development in the region was planned and implemented by the provincial government (Firman, 2010b). Thereafter, the provincial government only acted as a facilitating actor. The three local governments agreed to tackle regional infrastructure service provision problem together by creating a resource sharing system, including financial and personnel resources. They also established a joint secretariat as a managerial body and hired a professional from the nongovernmental organization to manage the day to day job and overseeing collaborative programs.

Regarding the working mechanisms of the collaboration, at the top of collaborative structure the mayors of three regions decide the main direction and common vision of cooperation. While the main agenda is drawn by the mayors, the lowest tier of collaborative management -a working group consists of local staff from the participating local governmentstechnically examines and discusses the project initiatives before proposing a specific project to the second tier consists of the head of the departments. Between the senior officers consensus is again discussed and developed, including the budget allocation and legal drafting, before the agreement is brought back to the mayors for signing the official agreement.

\subsection{Surabaya (Gerbang Kertasusila/GKS Metropolitan Region)}

With 9.1 million population (2010) and a total area of 5,862 $\mathrm{km}^{2}$, GKS Metropolitan Region (from this point forward referred as Surabaya) is the second biggest and populous metropolitan region in Indonesia, after the capital region. Its name comes from acronyms of two municipalities (Surabaya and Mojokerto) and five regencies (Gresik, Bangkalan, Mojokerto, 
Sidoarjo and Lamongan). The memorandum of collaboration in the region in 1986, initiated by the provincial government. The local government prepared its subordinate plan based on plan formulated by the provincial government and the Ministry of Public Works. During 1980s-1990s, there were limited information exchange and interaction among local governments in the region. At that time intergovernmental collaboration was considered only as a coordinating initiative and information sharing mechanisms as joint implementation was missing. The hypothetical assumption is that the metropolitan collaboration was an instrument for the provincial government to guide regional development.

After the decentralization, the provincial government retained its position as the coordinating agent while local governments gain more authority financially and administratively in developing plans for their area. With the sudden authority acquired, this study assumes that it is unsurprising to find a growing local egocentrism where local governments are only interested in bargaining with higher governments to maximize their own interest and have less concern to collaborate with their neighboring cities. This fragmented attitude has resulted in a number of challenges in bigger scale service delivery, which requires cross-jurisdictional collaboration. From the interview it is gathered that the current intergovernmental collaboration only covers a smaller scale of sectoral projects such as coordinating infrastructure planning along the border, mostly local road and sewerage improvement. The problem with limited collaboration is that the implementation heavily depends on the wistful intention of each local government in prioritizing the project on their budget allocation. However, although collaboration in this region is lacking in delivering the implementation, there is growing improvement in planning coordination. Continuous information exchange and interaction among neighboring local governments, which to a certain degree facilitated cities to reach consensus and building up mutual trust, are observed.

\subsection{JMA (Jakarta Metropolitan Area/Jabodetabek)}

The Jakarta Metropolitan Area or locally known as Jabodetabek covers Jakarta (the special capital province), the northeastern part of Banten province and the northwestern part of West Java province. The metropolitan area covers $6,400.71 \mathrm{~km}^{2}$ land and includes eight municipalities and regencies surrounding Jakarta -three in Banten province and five in West Java province. The Jakarta special capital province itself consists of five municipalities and one regency with no autonomous authority. There are 155 districts, 652 sub-districts and 848 villages under the administration of these 14 cities. The region is a home for 26.6 million inhabitant, counted of more than $10 \%$ of Indonesia's total population (2010). The density in the core city is $14,508 / \mathrm{km}^{2}$ making it as the most densely populated areas in the country. The region generates 24.1 percent of national GDP with Jakarta alone is counted as many as 16.90 percent.

The first effort to establish intergovernmental collaboration in the JMA started in 1976 with the formation of the metropolitan coordinating body called BKSP (Badan Kerjasama Pembangunan). It was formed by the provincial government of Jakarta and West Java. From 1976 to 1990s the coordinating body formed a top-down hierarchical type of collaboration to guide the regional development, especially to reduce the urbanization pressure in the core city. The master plan was formulated in a top-down process mostly due to JMA's status as an important national strategic area. In this sense, the central government through its ministerial bodies plays their role in planning and implementation process to ensure their interest comes through. 
Following the regional proliferation with the creation of one new province (Banten province) and three new municipalities which previously were part of West Java after the decentralization, the joint collaboration was renewed in 2004. Together the governors of Jakarta, West Java and Banten act as the head of the collaboration body supported by the executive secretariat as its managing agent. Under the BKSP, the master plan is again introduced while information exchange and interaction among various governments are encouraged. Despite this, the collaboration continues to center on issue and challenges surrounding the border of the capital province. Under the platform of BKSP, Jakarta special capital province forms partnership agreements with each municipality and regency along its border. In the recent years other cities in the region slowly emulate it and form their own partnership with neighboring cities.

In the wider frame, this study considers the collaboration under BKSP is similar to the one experienced in Surabaya; a coordinating forum without implementation capacity. A large part of the collaborative project is forged directly in sectoral basis between neighboring cities outside the platform of BKSP. In most cases, resources for implementing the collaborative project is financed by the capital province of Jakarta especially for projects that directly influence urban service provision in its jurisdiction. The financing scheme is usually formed on the basis of grants and in kind transfer.

\subsection{Denpasar (Sarbagita Metropolitan Region)}

Located in Bali province in central Indonesia, Sarbagita is one of three metropolitan regions situated outside the highly populated Java island (from this point forward referred as Denpasar). The metropolitan area consists of one municipality (Denpasar) as the core city and three regencies (Badung, Tabanan, and Gianyar). With the population of 2.2 million and a total area of $1,754 \mathrm{~km}^{2}$, it is less dense compared to other metropolitan regions in the Java island.

Cooperation in Denpasar is a collaborating forum to alleviate interrelated regional problems in the region. The cooperation was established before the central government acknowledged Denpasar as a metropolitan region in 2008. It was initiated based on the study facilitated by the World Bank in 1999, shortly after the decentralization law was enacted. The collaboration itself has been a gradual process evolving from informal, irregular information exchange among local governments. It works effectively starting from 2004 when each member signed a collaborative agreement, including sharing financial and human resources. Under this agreement platform, participating local governments formed collaboration based on their common interest, such as solid waste management and transportation (joint partnership with and initiated by the provincial government). Unlike Yogyakarta, Denpasar does not have a single joint cooperation body to manage all of their collaboration activities, instead it has several smaller joint managing agencies responsible for each sectoral cooperation.

Denpasar is essentially a bottom-up initiative with intergovernmental and cross-sectoral collaboration as well as a top-down intragovernmental collaboration. The bottom-up approach, for example, is the solid waste management program; initiated and managed by the local governments. The collaborating agent responsible for this program formed a contractual agreement with the private sector for managing the operation of the solid waste plant. This type of contracted planning and implementation between a group of local governments and the private sector is the first of such models developed in Indonesia. On the other hand, the collaboration in the transportation sector was initiated by the provincial government using the same platform as the solid waste management program to create a regional based mass 
transportation. The project is a joint collaboration between the central government, provincial government and the four local governments. Each local government is responsible to finance some part of the project with the provincial government as the managing and operational body.

Table-1. Metropolitan collaborative governance mechanism in Indonesia.

\begin{tabular}{lllll}
\hline Indicators & \multicolumn{1}{c}{ Yogyakarta } & \multicolumn{1}{c}{ Surabaya } & \multicolumn{1}{c}{ Jakarta } & Denpasar \\
\hline $\begin{array}{l}\text { Collective action } \\
\text { establishment }\end{array}$ & $\begin{array}{l}\text { Bottom-up } \\
\text { (local) }\end{array}$ & $\begin{array}{l}\text { Top-down } \\
\text { (provincial) }\end{array}$ & Top-down (central) & Bottom-up (local) \\
\hline Mechanism $^{1}$ & Voluntary & $\begin{array}{l}\text { Hierarchical, } \\
\text { hybrid (proposed) }\end{array}$ & $\begin{array}{l}\text { Hierarchical, } \\
\text { Hybrid (present) }\end{array}$ & Voluntary \\
\hline $\begin{array}{l}\text { Type of } \\
\text { coordinating body }\end{array}$ & Joint Secretariat & $\begin{array}{l}\text { Cooperation board } \\
\text { (provincial) }\end{array}$ & $\begin{array}{l}\text { Coordinating board } \\
\text { (central, provincial) }\end{array}$ & Coordinating \\
\hline Governmental & Local-local & Local-local & Provincial-provincial & Local-local \\
collaboration & & (limited) & Provincial-local & Provincial-local \\
\hline Financial sources & Provincial, local & Provincial, local, & Provincial, local, & Provincial, local, \\
& & private & private & private \\
\hline Main partners & Local, civic & $\begin{array}{l}\text { Local, private, } \\
\text { civic sector, state }\end{array}$ & $\begin{array}{l}\text { Local, private, civic } \\
\text { sector, state owned }\end{array}$ & $\begin{array}{l}\text { Local, private } \\
\text { sector }\end{array}$ \\
& sector & owned enterprise & enterprise & \\
\hline
\end{tabular}

${ }^{1}$ Luo and Shen, 2009. Note: Hybrid refers to mechanism mobilized by both higher levels of government and local government; Hierarchical is by higher levels of government; Voluntary is by the local government.

Table-1 above summaries the collaborative governance mechanism in the case studies, categorized according to the indicators drawn from the literature review. All information displayed are based on interviews with the local government agencies using a set of questions based on the indicators. The next part attempts to dissect its vertical and horizontal relations by using dimensional approach. It aims to gather a more detail explanation of interaction underlying the collaborative governance activities to reason why each collaboration formed differently.

\section{Measuring governance: A dimensional approach}

In spite of the multitude of recent empirical research on governance, a study addressing issues on how to conceptualize, measure and compare metropolitan regions with great precision seems to take on slower pace, even in the United States with its hundreds of metropolitan regions and advance research on collaborative governance (Miller, 2002; Hamilton et al, 2004; Miller and Lee, 2009). Miller and Lee (2009) specifically pointed out that lack of conceptual clarity of the unit of analysis in addressing metropolitan governance caused lagging capacity to distinguish patterns of governance among metropolitan regions with a similar level of structural fragmentation. Moreover, research on collaborative governance in Asian context is even more limited as most research only focuses on identifying macro aspects of collaborative governance such as effectiveness, mobilization and historical formation (Luo and Shen, 2009; Zul Fahmi et al, 2010; Firman, 2010b). There has been yet research regarding Asian metropolitan which delves into the structural differences of institutions in the metropolitan region and how this differences reflect on the collective behavior of each individual city. 
The measurement of vertical and horizontal interaction in the dimensional analysis is built on the basis of the operationalization of regionalism whereas; vertically, the more local governments are involved with regional institutions (in Indonesian case, the provincial institutions), the more they willing to adopt a regional perspective in their local development policy making process. The same rationale can be applied to other vertical interaction at other governance levels. Horizontally, the more local governments are involved with other local institutions, the more they willing to adopt a collaborative perspective. The vertical and horizontal interaction can be sought through either formal or informal relations to represent the nature of the structure of institutions that reflect the regularity of human behavior as explained in the new institutionalism theories (March and Olsen, 1989; Pierre, 1999; Ostrom, 2005).

This study generally sees the main idea of metropolitan taxonomy by Miller and Lee for US cases represent the similar operationalization of regionalism, building a path to analyze all types of relations occurred among actors in dimensional perspectives; vertically and horizontally. It defines the vertical dimension as the relationship between the higher level government and the constituent local governments within its jurisdiction. While a city charter defines the structure of city governance, the general grant of authority from the higher level government to local governments defines the vertical structure of regional governance (Miller and Lee, 2009). Horizontal dimension is described as basic relations occurred among the local actors.

The first step to apply this structured approach to measure collaborative governance in this study is by recognizing how the Indonesian system differentiates itself from the US system. Vertically, the Indonesian system consists of central, provincial and local governments interacting in a hierarchical manner. The vertical dimension of the governmental structure can be divided into two layers; the central-local government and the provincial-local government relations. However, the Indonesian metropolitan regions do not have formal regional institutions as the current system does not acknowledge a governmental structure at a supra-local level. Hence, the horizontal dimension of Indonesian governmental structure only consists of two layers: intergovernmental relations and cross-sectoral relations (see Figure-1).

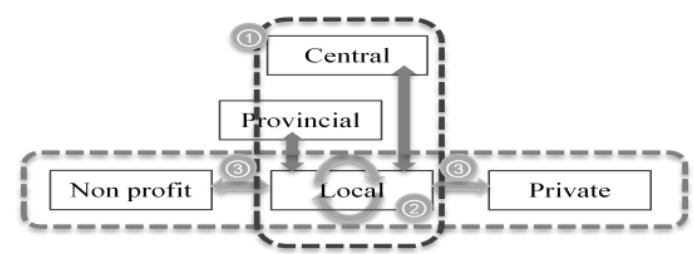

Figure-1. A dimensional model for classifying regional governance in Indonesia.

(Source: author)

In the US system, each state makes decisions about the purpose and nature of the local governments within its boundaries, making a possibility that the system could have 50 different vertical approaches (Miller and Lee, 2009). Unlike the US which employs a federal system at the national-state level, but a wide variety of unitary system at the state-local level, the political system of Indonesia is a framework of a presidential representative democratic republic. It is a unitary state with the power concentrated in the central government. After 1999, decentralization has reduced the authority of the central government and extended the authority of provincial and local governments thus making these governments able to initiate local policies. With this law, the local governments are much more independent in promoting their 
own interests, developing their own institutions, managing and mobilizing their own financial resources. In the same sense that the general grant of authority from the state to local governments defines the vertical structure of governance for the region in the US, the priority that central and provincial governments give to intragovernmental transfers including policy and fiscal dependency defines the vertical structure of governmental relations in Indonesia.

This study assumes that the state of Indonesian collaborative governance in the metropolitan region is closely related to the extend of the institutional structure of central-provincial-local governments, implying that interaction between actors advances collaboration more effective. Thus, the dimensional analysis in this study is designed in order to understand the structural dimension of the institution which is a part of exertion to gather a perspective on collaborative governance. Accordingly, the measurement to determine the structure of the institution uses collaborative activities as parameters. The aforementioned parameters in this analysis are defined broadly to encompass opportunities for linkages in many policy domains, although collaboration in planning is seen as the foremost.

The instruments used to measure the institutional structure of the collaborative governance were retracted from the collaborative governance activities survey originally developed by Agranoff and McGuire (2003). The parameters are seen as parsimonious, yet analytical as well, offering a thorough accounting of activity that parallels the bureaucratic management closely related in explaining the structure of institutions. The parameters are quite general in nature and can be used in multiple field of the planning sector or public management, yet this study limits its endeavor only on urban infrastructure provision. At this point, it is the only comparable collaborative policy field in all four regions observed as other fields are undertaken in one or two regions but not the others. Moreover, weight is added to the activities which more likely to involve interest's accommodation or policy integration since these type of activities represent an individual rational choice and norm of reciprocity that will promote voluntary cooperation (Axelrod, 1984). Weighting method used in the analysis is done by multiplying the result of certain activities by 2 times, effectively doubled the accumulative result from those activities. There is no specific reason by choosing to double the result other than to singled out the difference of cities which do or do not pursue weighted activities. Thus, it also can be done by multiplying them by 3 or 4 times if willing.

Vertical interaction is measured through two activities: information and adjustment seeking. In the former, local governments are expected to seek tactical assistance from the higher level institutions while the latter shows how they tend to adjust their programs to collective rules or regulations or seek some slack in hierarchical regulations. Adjustment seeking is particularly important because local governments are more likely to adopt a collective perspective in these kinds of policy interactions. They are generally initiated by localities requesting treatment that is not technically apparent within standards or regulations. According to Agranoff and McGuire (2003), cities that rely heavily on activities relative to adjustment-seeking can be viewed as employing a primarily top-down approach to managing as it is the prime examples of donor-recipient and jurisdiction-based activities. While information seeking activities are likely to be short-lived, adjustment seeking activities promote long-term relationships between local officials and officials in other levels of government. Regionalism is relatively easy to address in this context because city officials must jointly establish a course of action with provincial officials, who bring the regional perspective into the interaction. Thus, this type of activities should be weighted more because of their significance in the development of collective identity. 
Table-2. Measurement for dimensional analysis.

\begin{tabular}{llc}
\hline Vertical dimension & & Weighted \\
\hline Information seeking & New funding of programs and projects & \\
& Financial assistance & \\
& Policy guidance & \\
& Technical assistance & \\
& Review of plans/plan approval & \\
Adjustment seeking & Request resolution of conflicts with other local government & $\checkmark$ \\
& Change in policy (flexibility) & $\checkmark$ \\
\hline Horizontal dimension & & $\checkmark$ \\
\hline Joint policy efforts & Consolidate policy effort & $\checkmark$ \\
& Engage in formal partnership & $\checkmark$ \\
& Engage in the joint policy making & \\
& Engage in joint policy implementation & \\
Resources exchange & Pool/share financial resources & \\
& Pool/share personnel resources & \\
& Exchange information/share ideas & \\
Project based works & Partnership for particular project (planning) & \\
& Partnership for particular project (implementation) & \\
& Asset specifity and measurement (monitoring) & \\
\hline
\end{tabular}

Source: extracted from Agranoff and McGuire (2003).

The measuring of horizontal structure is an attempt to explain how local actors interact among interdependent linkages in building bases of supports, bargaining, and determining feasible courses of action within their allowed capacities. Joint policy making activities are where local governments include other horizontal actors, either formally or informally, in the planning, goal development, and decision-making tasks of collaborative policy making. The resource exchange involves seeking and acquiring resources from multiple actors, as well as combining and leveraging resources among actors. Project-based activities engage a multitude of local actors within the context of a particular project, either short or long term.

The structured survey targeted chief officers from local government (municipality/regency), working with the Local Development Planning Agency and City Planning/Public Works Agency who responsible for the planning and implementation of collaborative urban service provision activities in their respective cities. The Local Development Planning Agency is the local coordinating office for urban planning and development as well as the local think tank for policy making in all urban related issues. Generally, this agency is responsible for managing city at large, including governing collaboration. City Planning or Public Works Agency is selected as the respondent due to its involvement in policy and planning implementation of public infrastructure. Accordingly, these agencies are accountable in overseeing any joint partnership for projects and program implementation in urban service provision.

Respondents were interviewed and asked to check each activity they participate with various kinds of organizations, including central and provincial government agencies, neighboring city agencies, state owned enterprises as well as private and civic sector. The activities asked are widely elaborated from the measurement of dimensional analysis presented on Table-2. Respondent's experiences, accounts and opinions were documented through semi-structured interviews that were designed to encourage discussion about decision to collaborate with a certain actor. Table-3 lists the organizations and agencies of potential collaborative institutions asked to the respondent. 
Table-3. Lists of organizations/agencies.

\begin{tabular}{lll}
\hline Central level & Provincial level & Local level \\
\hline 1. National Planning & 1.Provincial Planning & 1.Local Development Planning Agency \\
Coordination Board & Coordination Board & 2.City Planning Agency/Department of \\
2. National Development & 2. Provincial Development & Public Works \\
Planning Agency & Planning Agency & 3.District office \\
3. Ministry of Public & 3.Provincial Public Works & 4. State owned company \\
Works/Ministry of Home & agency & 5.Chamber of commerce/Private sector \\
Affairs & & association \\
& & 6.Private sector and developers \\
& & 7.University \\
& & 10.Non Governmental Organization \\
\hline
\end{tabular}

The primary dimensional structure variable is the total number of interactions, measured as the sum of all vertical and horizontal linkages as reported by respondents. Respondents were asked to indicate which actors had been contacted in the last five years and for what activity. Two separate questionnaires are designed. The first questionnaire pertaining the vertical dimension asked the respondent to select whether any or all of central and provincial government agencies had been contacted and which of 7 vertical activities was pursued with each contact. Since both governments has 3 agencies each, cities could have made up to 21 contacts for each level of governments ( 7 activities, 3 actors). The second questionnaire refers the horizontal dimension, requested the respondent to select which (any or all) of 10 agencies (governmental and non governmental) in local level had been contacted, and which (any or all) of 10 activities was pursued. Since not all cities have the same exact operating agencies for implementing infrastructure, City Planning Agency and Department of Public Works are counted as one agency in the questionnaire -some cities have only either City Planning Agency or Department of Public Works or if they have both it is usually the latter that is responsible for infrastructure provision-. Similar condition is appraised for Chamber of Commerce and private sector association; medium to small size cities usually do not have them as two separate offices allocated for their cities, but rather under the regional offices, usually located in the capital of the province. Hence, for the horizontal interaction cities could have exercised up to 80 horizontal activities (10 activities, 8 actors).

Table-4. Data availability.

\begin{tabular}{lcccc}
\hline Metropolitan region & $\begin{array}{c}\text { No. of local } \\
\text { governments }\end{array}$ & $\begin{array}{c}\text { Total respondent } \\
\text { (collected) }\end{array}$ & \% response rate & $\begin{array}{c}\text { Period of } \\
\text { survey }\end{array}$ \\
\hline Jakarta & 9 & $18(16)$ & 88.89 & $*, * *$ \\
Surabaya & 7 & $14(12)$ & 85.72 & $*$ \\
Yogyakarta & 3 & $6(6)$ & 100.00 & $*$ \\
Denpasar & 4 & $8(5)$ & 62.50 & $* *$ \\
\hline
\end{tabular}

Period of survey: *: October - November 2012, **: May - June 2013.

Table-4 presents the overall situation of data collected from questionnaire survey. 12 cities were visited during October to November 2012 and officers from 11 cities were interviewed during May to June 2013. With one or two agencies interviewed in each city, there are 39 questionnaires collected in total. Each interview is usually conducted with a sole respondent or in a group type of discussion with several officers present. 


\section{Assessing the vertical and horizontal dimension}

The measurements of vertical and horizontal interaction activities are not normally distributed (see Table-5). In this sense, the incidence of all activities varies significantly. All cities report both vertical and horizontal interaction, albeit in different intensities.

Table-5. Descriptive statistics for dimensional arrangements.

\begin{tabular}{lccccc}
\hline \multirow{2}{*}{ Measure } & Total & \multicolumn{2}{c}{ Vertical dimension } & \multicolumn{2}{c}{ Horizontal dimension } \\
& IA & Central & Provincial & Local Gov't & Non Gov't \\
\hline Mean & 20.3 & 7.6 & 7.7 & 13.4 & 11.9 \\
Median & 18.0 & 7.0 & 7.0 & 14.0 & 12.0 \\
Standard deviation & 9.1 & 2.9 & 3.2 & 5.5 & 6.9 \\
High & 43.0 & 16.0 & 19.0 & 26.0 & 30.0 \\
Low & 5.0 & 3.0 & 2.0 & 1.0 & 2.0 \\
\hline
\end{tabular}

Table-6. The usage of vertical and horizontal activities.

\begin{tabular}{lcccccc}
\hline Activity & Max & \multicolumn{5}{c}{ Mean usage of activity } \\
& Score & All & Jakarta & Surabaya & Yogyakarta & Denpasar \\
\hline Vertical (Central) & & & & & & \\
Information seeking & 5.0 & 4.5 & 4.4 & 4.5 & 4.5 & 5.0 \\
Adjustment seeking & 2.0 & 0.9 & 0.8 & 1.0 & 0.7 & 1.0 \\
Vertical (Horizontal) & & & & & & \\
Information seeking & 5.0 & 4.1 & 4.2 & 3.0 & 4.8 & 5.0 \\
Adjustment seeking & 2.0 & 1.3 & 1.2 & 1.3 & 1.3 & 2.0 \\
Horizontal (Local Government) & & & & & & \\
Joint policy effort & 4.0 & 3.3 & 3.6 & 2.2 & 3.7 & 4.0 \\
Resources exchange & 3.0 & 2.1 & 2.2 & 1.2 & 2.8 & 2.6 \\
Project-based works & 3.0 & 2.2 & 2.2 & 1.7 & 2.7 & 2.8 \\
Horizontal (Non Governmental) & & & & & & \\
Joint policy effort & 4.0 & 2.2 & 2.5 & 2.3 & 1.0 & 2.2 \\
Resources exchange & 3.0 & 1.8 & 1.6 & 1.7 & 1.7 & 2.6 \\
Project-based works & 3.0 & 2.2 & 2.2 & 2.0 & 1.5 & 3.0 \\
\hline
\end{tabular}

Use: The average number of activities exercised by respondents regardless the counterpart agency (only the origin of the counterpart is considered). Ex.: 4.0 use of information seeking (max. 5.0) means that in the average cities exercise 4 out of 5 information seeking activities asked in the questionnaire.

Max score: maximum number of activities available/asked to the respondent.

The usage of vertical and horizontal interaction activities (Table-6) displays the average activities exercised by the local government towards its counterpart. On average, cities perform approximately 4.1 to 4.5 (out of 5) of information seeking activities and 0.9 to 1.3 (out of 2) of adjustment seeking activities to the central and provincial government respectively. The usage of horizontal interaction activities informs us that the majority of cities conducts their joint policy effort with neighboring local governments more than with the non governmental actors in their cities. By the usage, cities in the Yogyakarta metropolitan region submit the most polarized results, implying that they rely mostly on their neighbors by devoting their horizontal activities twice as active compares to the non governmental actors. Cities in the Surabaya metropolitan region are, in average, the most passive and cities in the Denpasar metropolitan region are the most active regardless the counterparts. These indicate that the relations among local governments in Surabaya are not as strong as others and cities less actively pursue intergovernmental interaction as oppose to the non governmental interaction. 
When there is a significant variance found in the usage of respondents using vertical and horizontal activities, the next step needed is to detect a meaningful difference in the structural dimension of the institutions to gather a procedural perspective of collaborative governance. By doing so, this study expects significant regional differences in the level of collaboration. These variations are necessary in observing the impact of the institutional structure as one of the factors that influence the collaborative tendency at the local level as well as the propensity to collaborate with certain actors. Five variables were defined in accordance with the origin of respondent's counterpart. These variables, which are labeled Central Interaction (CI), Provincial Interaction (PI), and Horizontal Interaction (HI) were illustrated the levels of government. The Horizontal Interaction is further differentiated based on the origin of respondent's counterpart on the local level; Intergovernmental Interaction (IG), and Cross-Sectoral Interaction (CS). Both Central and Provincial Interaction were measured from the vertical dimensional activities while Intergovernmental and Cross-Sectoral Interaction were derived from the horizontal dimensional activities. All of the variables are aimed to measure the intensity of interaction between local governments with the provincial institutions (regional based), the central institutions (national based), other neighboring local government institutions, and local non governmental institutions, respectively.

Table-7. Mean of dimensional arrangements.

\begin{tabular}{|c|c|c|c|c|c|}
\hline & Max Score & Jakarta & Surabaya & Yogyakarta & Denpasar \\
\hline \multicolumn{6}{|l|}{ Vertical dimension } \\
\hline Central interaction (CI) & 21.00 & $7.06(8.12)$ & $7.30(8.90)$ & $9.17(10.67)$ & $8.20(9.60)$ \\
\hline Provincial interaction (PI) & 21.00 & $7.00(8.17)$ & $6.30(8.10)$ & $11.67(14.00)$ & $10.20(13.00)$ \\
\hline \multicolumn{6}{|l|}{ Horizontal dimension } \\
\hline $\begin{array}{l}\text { Overall Horizontal } \\
\text { interaction }(\mathrm{HI})\end{array}$ & 80.00 & $25.58(32.24)$ & $22.80(30.33)$ & $27.17(34.83)$ & $32.60(41.40)$ \\
\hline $\begin{array}{l}\text { Intergovernmental } \\
\text { interaction (IG) }\end{array}$ & 30.00 & $11.65(15.53)$ & $9.20(11.70)$ & $18.67(24.00)$ & $17.00(22.60)$ \\
\hline Cross-sectoral interaction & 50.00 & $15.12(18.06)$ & $13.70(16.80)$ & $6.83(8.00)$ & $15.60(18.80)$ \\
\hline
\end{tabular}

Note: Bracketed numbers are weighted results.

Table-7 shows the structural pattern of collaborative governance in four observed regions. The information given from the results demonstrated that the pattern of vertical interaction for both central and provincial is fairly diversified in the four regions. The result of the provincial interaction follows a similar pattern as the central interaction where a significant score gap occurred between two regional groups. Yogyakarta and Denpasar are on one side and the other two regions are on another side. Yogyakarta maintains a high level of activities with its provincial government, almost doubled compared to Surabaya. Denpasar, although display slightly less score of provincial interaction compared to Yogyakarta, is still much higher than the remaining two.

The horizontal dimension produces the most complex results of all the indices in both intergovernmental and cross-sectoral interaction, with Surabaya and Yogyakarta are located at the extreme ends of the spectrum and Jakarta falls in the middle. Whereas cities in the Yogyakarta metropolitan region are the most frequent users of the intergovernmental interaction, they are the least frequent users of the cross-sectoral interaction. The score is strikingly different, implying that Yogyakarta employs a limited cross-sectoral collaboration and more focused to 
develop their intergovernmental structural institutions. On the other hand, instead of interacting with their neighboring cities, the local governments in the Surabaya metropolitan region tend to put more focus to form a collaboration with the non-governmental organizations. Jakarta and Denpasar also showcase a high cross-sectoral interaction, pursuing about twice and half as many cross-sectoral interaction than cities in the Yogyakarta metropolitan region.

When the extent of change from unweighted to weighted measures for the vertical dimension is compared, it is found that Surabaya shows the biggest change, which indicates that local governments in the region are involved more in adjustment-seeking activities with the central and provincial governments among other observed regions. This means that the region puts more consideration and emphasis towards activities to accommodate its interest to the higher-level governments. Horizontally, a closely similar value percentage increase in the intergovernmental interaction shows that all four regions have a corresponding view on their priority in developing its intergovernmental collaborative environment (raises ranging from 26 to 33 percent). The change on the cross-sectoral interaction is more diverse with Surabaya puts the most changes (in percentage), followed by Denpasar, Jakarta and Yogyakarta. This further confirms the collaborative preference of each region, whereas Surabaya is less likely to have interest to collaborate with its neighboring municipalities than with the public or private sector and Yogyakarta employs the exact opposite preferences. It can be translated that the local governments in the Surabaya metropolitan region are more open in accommodating non-governmental sectors in their planning and infrastructure provision, while the local governments in the Yogyakarta metropolitan region is more accommodating towards other governmental entities. However, policy analysis should be done to confirm this assumption.

\section{Discussion}

One important aspect of this result is that it rejects the common belief implying that Jakarta as a capital region has a legacy of closer relations with the central government. This claim may have been correct prior to the decentralization when Indonesian government system is highly administratively and politically centralized and hierarchical at best where central government controlled all aspects of planning. At that time, as the capital region, Jakarta had been given development priority which resulted in the high level of primacy compared to other major cities across Indonesia. In the post decentralization era rather than closer proximity, proactive approach from local government to central government plays more important role in shaping local-central interaction. The city must constantly pursue opportunities that available in the central level creating a competitive based relation with other cities for the central government programs and funds. Indeed, in this study, the Jakarta metropolitan region demonstrates about the same level of activity with the Surabaya metropolitan region and has less activity compared to Yogyakarta and Denpasar.

As vertical interaction varies between regions, the horizontal interaction followed. From the analysis this study gathers that the local-central interaction in neither positively nor negatively directly affects the intergovernmental and cross-sectoral interaction. This finding implies that the central government has less hand in horizontal relations. On the other hand, it seems that the local-provincial interaction is positively related to the extent of intergovernmental relations, although its correlation with the cross-sectoral interaction is rather unclear at this point. Both Yogyakarta and Denpasar exhibit higher level of interaction with the provincial government and a higher intergovernmental interaction compared to Jakarta and Surabaya. 
Concerning the contrasting results of the central and provincial interaction, this study assumes that several conditions trigger these vertical actions: incompatibility of central provincial expectations with local needs or interests, laws or regulations that impeded local development projects and programs, and less than desirable contacts between cities and its higher governments due to multiple reasons politically and personally (between officials). Given the difficulty of making the appropriate contacts and developing some understandings of the conditions under which the central or provincial government is more apt to grant discretion, these negotiations and bargaining activities between local government as both 'the recipient and pursuer' and the central or provincial government as 'the regulated' are important in the vertical structural relations.

Looking into the detail of the provincial interaction, it is partially understandable that the Yogyakarta metropolitan region enjoys a higher level of provincial interaction given it is also a special province where the sultanate system still employs a strong influence upon the provincial governance system. Unlike other provinces in Indonesia, in Yogyakarta the head of the province is not directly elected by citizen but an inherited position given to the sultan. Historically, it has a strong Javanese tradition embedded in its social and political culture which is hierarchical in nature. Denpasar does not hold a special status like Yogyakarta, hence the closeness between the cities and the provincial government is much greater than this study anticipated at the outset. Our presumption is that this relation is temporary rather than hereditary -as Yogyakarta- and regular contacts are offered through both sides of governments thus making the local government not the only part actively pursuing the relations. In this sense the provincial government must have played its part as the regional organization and is not just an agent of the central government, which are both necessary for regional governance in a decentralized system to function properly.

In the horizontal dimension, the inference this study formed from the vast different results comparing the intergovernmental and cross-sectoral interaction is both interactions are affected by several circumstances: the potential cost or burden of regulations, restrictive eligibility rules or funding regulations for the financial and personnel sharing scheme, standards that local partners (both governmental and non governmental) in a collaboration effort could not meet, incompatibility of intended partners expectations with cost spent, the availability of counterparts and their resources, and good willing from all local actors. Negotiations and bargainings in building horizontal interaction regardless the counterparts are a vital part as the difficult process of creating a horizontal structure of institutions. The premise of potential cost in horizontal interaction can be partially explained as local governments more willing to meet and discuss ideas and approaches horizontally than vertically, but reluctant to part with finances or staff on programs or projects that involved resource commitment. This kind of reluctance is rarely found in the vertical interaction as the central and provincial government are the ones that possess a larger resource offered.

\section{Concluding remarks}

Cities seek information, financial and technical supports while trying to comply with regulations. In the Indonesian context, cities manage intergovernmental and cross-sectoral relations through negotiations with local actors as well as pursuing adjustment with the central and provincial government. Managing at the boundaries of governments is more complicated than expected. How cities operate their vertical and horizontal interaction varies between 
regions. These interactions represent the structure of institutions from the perspective of local government in pursuing multi dimensional activities, illustrating the nature of collaborative governance at the local level.

Empowerment is based on information rather than authority and one of its possible ingredients in its flows that are necessary is social capital (Agranoff and McGuire, 2003). As presented in the analysis, the usage of information and resources gathering activities among local actors have yet been maximized. The possible hindrances of collaborative governance in horizontal dimension as mentioned above -regulations, standards, incompatibility, resource availability, etc.- show some optional chances to move towards improvement that can be taken by the local government. Moreover, this study gathers that joint policy making and resource exchange activities in Indonesian collaborative governance are generally a government based activity where the presence of other actors are lacking. Resource exchange in particular becomes a force of cohesion within the collaboration that has yet been addressed in many, especially in the cross-sectoral interaction. As collaborative governance functions in an interactive environment based on the exchange, building up capacity in these types of activity will benefit cities to improve their collaborative environment.

The dimensional analysis opens a window to measure collaborative governance in more detailed manner since it evaluates the relationship structure the local government builds with other actors. As relations play an important role in collaboration, understanding its structure will help participating actors to gain a perspective on how to improve collaboration as well as its institutional capacity. This paper empirically documented the variety of collaborative interaction in the Indonesian metropolitan region concerning the urban infrastructure provision. However, a number of behavioral related questions remain that must be addressed in this study to gather a more comprehensive perspective of collaborative governance. Trust, leadership and cultural characteristics are another potential contribution to collaboration that are commonly accepted which has not been explored empirically in this study. Furthermore, while segregating cities based on its regions for comparative studies is necessary to see how different each region is, differentiate cities by their collaborative strategies, policies, spatial structure and fiscal power also hold possibilities to give further understanding.

\section{References}

1) Agranoff, R., and M. McGuire., 2003. Collaborative public management: New strategies for local governments. Washington, D.C.: Georgetown University Press.

2) Axelrod, R., 1984. The evolution of cooperation. New York, NY: Basic Books, Inc.

3) Brenner, N., 2002. Decoding the newest metropolitan regionalism in the USA: A critical overview. Cities, 19(1): 3-21.

4) Carr, J. B., and R. C. Feiock, eds, 1999. Metropolitan government and economic development. Urban Affairs review, 34(3): 476-488.

5) ___ 2003. Reshaping local government landscape: City-county consolidation and its alternatives. Armonk, N.Y.: M. E. Sharpe.

6) Fama, E. F., and M. C. Jensen, 1983. Separation of ownership and control. Journal of Law and Economics, 26: 301-325.

7) Feiock, R. C., ed, 2004. Metropolitan governance: Conflict, competition, and cooperation. Washington, D.C.: Georgetown University Press.

8) Firman, T., 2010a. Decentralization reform and local-government proliferation in 
Indonesia: Towards a fragmentation of regional government. Review of Urban and Regional Development Studies, 21(2): 143-157.

9) ___ 2010b. Multi local-government under Indonesia's decentralization reform: The case of Kartamantul (The Greater Yogyakarta). Habitat International, 34: 400-405.

10) Hamilton, D. K., D. Y. Miller, and J. Paytas, 2004. Explaining the horizontal and vertical dimensions of the governing of metropolitan regions. Urban Affairs Review, 40(2): 147-182.

11) Lubell, M., M Schneider, J. Scholz, and M. Mete, 2002. Watershed partnerships and the emergence of collective action institutions. American Journal of Political Science, 46(1): 148-163.

12) Luo, X., and J. Shen, 2009. A study on inter-city cooperation in the Yangtze river delta region, China. Habitat International, 33: 52-62.

13) March, J. G., and J. P. Olsen, 1989. Rediscovering Institutions. The Organizational Basic of Politics. New York: The Free Pass.

14) Miller, D. Y., 2002. The regional governing of metropolitan America. Boulder, CO: Westview Press.

15) Miller, D. Y., and J. H. Lee., 2009. Making sense of Metropolitan Regions: A dimensional approach to regional governance. Publius: The Journal of Federalism, 41(1): 126-145.

16) Mizruchi, M., 1983. Who controls whom? An examination of the relation between management and boards of directors in large corporations. Academy of Management Review, 8: 426-435.

17) Ostrom, E., 1990. Governing the commons: The evolution of institutions for collective action. New York: Cambridge University Press.

18) ___ 2005. Understanding Institutional Diversity. Princeton, NJ: Princeton University Press.

19) Pierre, J., 1999. Models of Urban Governance: The Institutional Dimension of Urban Politics. Urban Affairs Review, 34 (3), pp. 372-96.

20) Provan, K. G., 1980. Board power and organizational effectiveness among human service agencies. Academy of Management Journal, 23: 221-236.

21) Rhodes, R.A.W., 1997. Understanding Governance: Policy Networks, Governance, Reflexivity, and Accountability. Philadelphia, PA: Open University Press.

22) Sellers, J. M., 2002, Governing from Below: Urban Regions and the Global Economy. Cambridge: Cambridge University Press.

23) Situmeang, I.M, 2011. Repositioning the role of the governor in the local governance, Kompas: Political article (in Indonesian).

24) Stoker, G., 2000. Urban Political Science and the Challenge of Urban Governance. In J. Pierre (ed.), Debating Governance. Houndmills, Basingstoke, Hampshire: Palgrave Macmillan.

25) Weber, E. P., 1998. Pluralism by the rules: Conflict and cooperation in environmental regulation. Washington, D.C.: Georgetown University Press.

26) Wheeler, S.M., 2002. The new regionalism: Key characteristics of an emerging movement. Journal of the American Planning Association, 68(3): 267-278.

27) Zul Fahmi, F., D. Hudalah, and T. Firman, 2010. Lesson from inter-local government cooperation effectiveness in Greater Yogyakarta. Regional and Rural Planning Research Group, School of Architecture, Planning and Policy Development, Institut Teknologi Bandung: Working paper no. 01-2010: 6-26. 